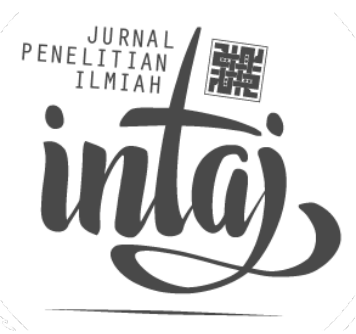

\title{
MEKANISME REKRUITMEN CALON BUPATI DALAM PEMLLIHAN UMUM KEPALA DAERAH SECARA LANGSUNG TAHUN 2015 DI KABUPATEN LAMPUNG SELATAN
}

Emiraldo Win Pazqara (emiraldovdh@gmail.com)

Universitas Wijayakusuma Purwokerto

\begin{abstract}
The purpose of this research was to know the recruitment process performed by National Mandate Party in recruiting Government Regent Candidate in the general election of district head directly in South Lampung at 2015. Method used in this research was qualitative experiment method with interactive analysis. Result of the research based on interview, observed documentation files, and the rule of law as guided in recruitment process by National Mandate Party South Lampung, showed that recruitment process at National Mandate Party was open with several indicators: (1) open candidacy for public in other words there is no party cadre monopoly; (2) several candidates were socialized in order to get response and idea from public; (3) selected candidates were established through convention democratically and can be accepted by society.
\end{abstract}

Keywords: Recruitment, Government Regent, South Lampung 


\section{PENDAHULUAN}

Otonomi Daerah merupakan unsur penting dalam pengorganisasian demokrasi, yang secara prinsip menekankan pembagian kekuasaan antara pemerintah tingkat nasional dengan unit-unit subnasional di bawahnya. ${ }^{1}$ Pembagian kewenangan kekuasaan dari pusat ke daerah tersebut merupakan salah satu contoh dari pelaksanaan demokrasi secara nyata.

Menurut Inu Kencana Syafei $d k k^{2}$ otonomi daerah itu sendiri berarti hak, wewenang dan kewajiban suatu pemerintahan daerah untuk mengatur dan mengurus rumah tangganya sendiri. Secara fungsionalisasi dalam otonomi daerah, fungsi mengatur diberikan kepada aparat legislatif yaitu DPRD, sedangkan fungsi untuk mengurus diserahkan kepada eksekutif daerah, yaitu kepala daerah dan dinas-dinas otonomnya yang berada di bawahnya.

Dalam rangka otonomi daerah diperlukan kombinasi yang efektif antara visi yang jelas serta kepemimpinan yang kuat dari pemerintah pusat, dan diberikannya keleluasaan berprakarsa dan berkreasi dari pemerintah pusat kepada pemerintah daerah. Oleh sebab itu otonomi daerah merupakan suatu manifestasi dari pelaksanaan demokrasi pada lapisan bawah.

Otonomi adalah buah dari kebijakan desentralisasi dan demokratisasi. Oleh sebab itu otonomi daerah harus dipahami sebagai sebuah proses untuk membuka ruang bagi lahirnya kepala pemerintahan daerah yang dipilih secara demokratis, memungkinkan berlangsungnya penyelenggaraan pemerintahan yang responsif terhadap kepentingan masyarakat luas, dan dapat memelihara suatu mekanisme pengambilan keputusan yang taat pada asas pertanggungawaban publik. Di samping itu, otonomi daerah juga berarti memberikan kesempatan untuk membangun struktur pemerintahan yang sesuai dengan kebutuhan daerah, membangun sistem dan pola karier politik, dan membangun administrasi yang kompetitif, serta untuk mengembangkan sistem manajemen pemerintahan yang lebih efektif dan tepat sasaran. ${ }^{3}$

\footnotetext{
${ }^{1}$ Thomas Meyer, Demokrasi Sebuah Pengantar untuk Penerapan, (FES Kantor Perwakilan Indonesia, Jakarta, 2004), hlm. 25

${ }^{2}$ Inu Kencana Syafiie et al., Sistem Pemerintahan Indonesia, (PT Rineka Cipta, Jakarta, 2002), hlm. 94

${ }^{3}$ H.R. Syaukani et al., Otonomi Daerah dalam Negara Kesatuan, (Pustaka Pelajar, Yogyakarta, 2004), hlm. 173-174
} 
Inti pelaksanaan otonomi daerah adalah terdapatnya keleluasaan pemerintah daerah (discretionary power) untuk menyelenggarakan pemerintahan sendiri atas dasar prakarsa, kreativitas dan peran serta aktif masyarakat dalam rangka mengembangkan dan memajukan daerahnya. Memberikan otonomi daerah tidak hanya berarti melaksanakan demokrasi di lapisan bawah, tetapi juga mendorong suatu otoaktivitas untuk melaksanakan sendiri apa yang dianggap penting bagi lingkungan sendiri. ${ }^{4}$

Setelah pemilihan umum legislatif dan pemilihan umum presiden yang berlangsung secara damai dan demokratis pada tahun 2004, praktek demokrasi di Indonesia tengah memasuki tonggak sejarah baru, yakni untuk pertama kalinya seorang gubernur, bupati, dan atau walikota dipilih secara langsung oleh rakyat melalui pemilihan kepala daerah secara langsung. ${ }^{5}$

Secara yuridis, urgensi dari pelaksanaan pemilihan kepada daerah secara langsung adalah sebagai konsekuensi dari diadakannya pemilihan presiden secara langsung tahun 2004 untuk pertama kalinya sebagai bagian dari demokratisasi. Diadakannya pemilihan presiden secara langsung yang merupakan demokratisasi di tingkat pusat, sudah semestinya juga berlangsung di tingkat lokal agar terdapat sinergi antara pemerintah daerah dengan pemerintah pusat, karena demokratisasi itu sendiri dimulai dari tingkat yang lebih rendah.

Pemilihan kepala daerah secara langsung merupakan bagian dari agenda reformasi dalam rangka membangun kualitas demokrasi yang lebih baik, khususnya demokrasi di tingkat lokal. Secara teoritis, pemilihan kepala daerah secara langsung merupakan pencapaian kemajuan dalam berdemokrasi. Melalui pemilihan kepala daerah secara langsung maka diharapkan: pertama, untuk meningkatkan kredibilitas dan akuntabilitas para elit politik lokal, mengurangi fenomena money politics, serta memotong oligarki partai. Kedua, menciptakan stabilitas dan efektivitas pemerintahan di tingkat lokal serta mendorong kualitas seleksi kepemimpinan nasional. Ketiga, meningkatkan kesadaran dan kualitas

\footnotetext{
${ }^{4}$ J. Kaloh, Mencari Bentuk Otonomi Daerah, (Rineka Cipta, Jakarta, 2002), hlm. 57

${ }^{5}$ M. Soebiantoro, Pemilihan Kepala Daerah Langsung dan Dilema Demokratisasi di Tingkat Lokal, dalam makalah seminar nasional, Jurusan Ilmu Politik UNSOED (2005), hlm. 1-2
} 
partisipasi masyarakat dalam politik serta memperkuat pelaksanaan otonomi daerah. Keempat, mendukung pelaksanaan demokrasi di tingkat nasional, karena demokratisasi pada tataran nasional hanya dapat terbangun apabila demokrasi juga berlangsung di tingkat lokal. ${ }^{6}$

Pemilhan umum kepala daerah secara langsung merupakan wujud pendewasaan politik bagi rakyat, terutama di daerah-daerah yang selama ini kurang begitu mendapatkan pendidikan politik secara kualitatif. Pemilihan umum kepala daerah secara langsung tersebut merupakan pembelajaran demokrasi pertama dalam era transisi ini, dan diharapkan hasilnya dapat memuaskan seluruh masyarakat, karena masyarakat dilibatkan secara langsung untuk memilih pemimpinnya. Pemilihan kepala daerah secara langsung juga merupakan suatu penghormatan kepada masyarakat, karena keberadaan mereka dihargai dengan dilibatkannya mereka secara langsung untuk memilih pemimpinnya.

Jadi, pemilihan umum kepala daerah secara langsung merupakan wujud dari pemberdayaan masyarakat dalam bidang politik, yang diharapkan adanya partisipasi aktif dari masyarakat untuk berperan langsung dalam proses politik, yaitu dengan memilih seorang pemimpin yang dapat memberikan kontribusi positif bagi perkembangan daerahnya.

Akan tetapi, pelaksanaan pemilihan umum kepala daerah secara langsung ini bukan berarti tidak ada kelemahannya, model baru sepanjang proses demokratisasi di Indonesia itu sudah pasti banyak mengandung konsekuensi dan dampak.

Sebagai dampak dari penyelenggaraan pemilihan kepala daerah secara langsung yang pertama kali, maka yang terlihat sekarang ini adalah terjadinya tarik-menarik antara kepentingan kelompok, sedangkan di pihak lain adanya keinginan untuk membangun fondasi demokrasi yang lebih kokoh di Negara ini. Meskipun pemilihan kepala daerah secara langsung dimulai dari scope yang lebih sempit yaitu di tingkat lokal (Provinsi, Kabupaten, dan Kota), namun dampaknya dapat terasa secara nasional, yaitu kredibilitas dari pemerintah yang sedang berkuasa pun ikut diuji.

${ }^{6}$ Ibid., hlm. 2 
Selain unsur primordial atau keterkaitan psikologis antara bakal calon dan konstituen yang lebih dekat sangat sulit untuk dieliminasi. Proses penyaringan calon dalam rangka pemilihan kepala daerah secara langsung sendiri belum menjamin akan berjalannya prinsip nilai-nilai demokrasi sebagaimana mestinya.

Sejak dimulainya pemilihan kepala daerah secara langsung pada awal bulan Juli 2005 di beberapa daerah, sampai pada tahap penghitungan suara tampaknya kita disuguhi oleh suatu kenyataan pahit, bagaimana tidak siapnya kita melaksanakan demokratisasi sebagai suatu mekanisme politik yang merujuk pada ketidakdewasaan dalam menerima prinsip sportivitas dalam relasi kompetisi yang mereka ikuti. Kesalahan bukan hanya pada suatu kenyataan, bahwa doktrin demokrasi yang kurang dipahami dengan melihat dari satu sisi seperti kacamata kuda, tetapi kesalahan lebih nyata tampak pada para actor politik yang memasuki arena kompetisi dalam kondisi yang tidak siap. ${ }^{7}$

Ditambahkan lebih lanjut, bahwa peran dari partai politik yang mengusung kandidat atau calon-calon tertentu seolah-olah lepas tangan setelah syarat-syarat yang ditentukan partai dipenuhi secara memuaskan oleh elit sepanjang masa pengusulan. Kesan yang terlihat sekarang ini adalah seolah partai politik yang mengusulkan calon tidak merasa ikut memikul tanggung jawab untuk mengendalikan situasi pascapertarungan pemilihan kepala daerah secara langsung dimulai.

Persoalan muncul manakala ada kecenderungan partai-partai untuk menjual tiket masuk bagi para pasangan calon dengan harga yang begitu mahal. Sudah dapat diduga, bahwa kepala-kepala daerah hasil pemilihan kepala daerah secara langsung tersebut hanya akan sibuk "mengembalikan modal" mereka daripada melayani kepentingan rakyatnya. Potensi Korupsi, Kolusi, dan Nepotisme (KKN) dapat berawal dari mekanisme pencalonan seperti ini. ${ }^{8}$

Sudah dapat diprediksi, bahwa kewajiban sewa perahu yang tentunya tidak murah dan sistem satu pintu yang menyandera para calon pemimpin daerah ini, di

\footnotetext{
${ }^{7}$ Maruarar Siahaan, Pemilihan Kepala Daerah dalam Demokrasi Transisional, (Mahkamah Konstitusi Republik Indonesia, Jakarta, 2005), hlm. 1

${ }^{8}$ M. Soebiantoro, loc.cit.
} 
kemudian hari bisa menjadi sesuatu yang harus dibayar mahal dan bagi proses demokratisasi itu sendiri.

Dalam penyelenggaraan pemilihan kepala daerah secara langsung di Kabupaten Lampung Selatan, ada tiga kandidat yang bertarung untuk memperebutkan kursi kepala daerah, yaitu 1). Soleh Bajuri berpasangan dengan Ahmad Ngadelan Jawawi (dicalonkan oleh dua partai, yaitu PKB dan Gerindra); 2). Rycko Menoza dan Eki Setyanto (dicalonkan oleh empat partai, yaitu Demokrat, Hanura, Golkar dan PBB); 3). Zainudin Hasan dan Nanang Ermanto (dicalonkan oleh empat partai, yaitu PAN, PKS, PDIP dan Nasdem).

Berdasarkan hasil rekapitulasi penghitungan suara pemilihan umum kepala daerah dan wakil kepala daerah Kabupaten Lampung Selatan pada tahun 2015 yang dilakukan oleh KPUD Kabupaten Lampung Selatan, jumlah perolehan suara sah untuk seluruh pasangan kepala daerah dan wakil kepala daerah adalah 486.808 suara dan jumlah perolehan suara tidak sah sebesar 8.153 suara. Kemudian dari keseluruhan jumlah perolehan suara yang sah tersebut, pasangan Zainudin Hasan dan Nanang Ermanto yang diusung PAN mampu mengungguli 2 pasangan lainnya dengan memperoleh 283.336 suara. Sedangkan kedua pasangan kepala daerah dan wakil kepala daerah lain memperoleh suara sebagai berikut ${ }^{9}$ :

a. Rycko Menoza dan Eki Setyanto: 185.669 suara.

b. M. Soleh Bajuri dan Ahmad Ngadelan Nawawi: 18.945 suara.

Pasangan Dr. H. Zainudin Hasan, M.Hum. dan Nanang Ermanto ini mampu menang di enam belas kecamatan dari 17 kecamatan yang ada di Kabupaten Lampung Selatan. Keenam belas kecamatan tersebut adalah Bakauheni, Candipuro, Jati Agung, Kalianda, Katibung, Ketapang, Merbau Mataram, Palas, Penengahan, Rajabasa, Sidomulyo, Sragi, Tanjung Bintang, Tanjung Sari, Way Panji, dan Way Sulan.

Adapun penetapan Partai Amanat Nasional (PAN) untuk dijadikan sasaran dalam penelitian ini, karena peranan partai ini yang telah sukses dalam memenangkan calonnya yaitu pasangan Zainudin Hasan - Nanang Ermanto dalam pelaksanaan pemilihan kepala daerah langsung tahun 2015 di Kabupaten Lampung Selatan dengan mengalahkan calon petahana.

\footnotetext{
${ }^{9}$ Komisi Pemilihan Umum, Pilkada Kabupaten Lampung Selatan, dalam https://pilkada2015.kpu.go.id/lampungselatankab, diakses 21-Juni-2016.
} 
Perlu ditambahkan disini bahwa pemilukada tahun 2015 di Kabupaten Lampung Selatan ini merupakan rematch atau pertarungan ulang antar dua kandidat yakni Rycko Menoza - Eki Setyanto dengan Zainudin Hasan yang ketika di pemilukada sebelumnya (2010) berpasangan dengan Ikang Fauzi.

Dari latar belakang masalah di atas dapat dilihat bahwa berhasil tidaknya calon bupati atau walikota untuk maju ke kancah pertarungan dalam pemilihan umum kepala daerah secara langsung, tidak lepas dari peranan partai politik yang menjadi perantara bahkan rekruitor bagi calon tersebut.

Berdasarkan latar belakang tersebut, tulisan ini bertujuan mendeskripsikan bagaimana pelaksanaan proses rekruitmen calon bupati dari Partai Amanat Nasional dalam Pemilihan Umum Kepala Daerah secara langsung tahun 2015 di Kabupaten Lampung Selatan.

\section{METODE PENELITIAN}

Metode penelitian yang di gunakan dalam penelitian ini adalah metode deskriptif kualitatif, yakni informasi atau data yang dikumpulkan tidak dalam bentuk angka, tetapi dengan menggunakan prinsip logika. Menurut Bogdan dan Taylor dalam Moleong ${ }^{10}$, metode kualitatif diartikan sebagai prosedur penelitian yang menghasilkan data deskriptif berupa kata-kata yang tertulis maupun lisan dari informan dan perilaku yang dapat diamati.

Dipilih metode kualitatif karena dalam penelitian ini berusaha memberikan gambaran mengenai proses rekruitmen calon bupati oleh Partai Amanat Nasional Lampung Selatan yang mana semua data yang diperoleh dari penemuanpenemuan tidak dapat dicapai dengan menggunakan prosedur statistik atau dari cara-cara lain dari kuantifikasi (pengukuran).

Penelitian ini dilaksanakan di Kabupaten Lampung Selatan Provinsi Lampung. Sedangkan situs penelitian ini yaitu di Kantor DPD II Partai Amanat Nasional Kabupaten Lampung Selatan.

${ }^{10}$ Lexy J. Moleong, Metode Penelitian Kualitatif, (PT Remaja Rosdakarya, Bandung, 2004), hlm. 3 
Sumber data dalam penelitian ini diperoleh melalui dua sumber, yaitu sumber data primer dan sumber data sekunder. Teknik pengumpulan data dalam penelitian ini menggunakan beberapa teknik pengumpulan data, yakni wawancara, observasi, dan dokumentasi. Fokus kajian dalam penelitian ini ada pada tabel 1 di bawah ini:

Tabel 1.1 Fokus kajian

\begin{tabular}{ll}
\hline Aspek-aspek & Instrumen \\
\hline Proses yang terbuka atau tertutup & - Pola Classified positions/exempt positions; \\
& - Kesempatan bagi semua kalangan/terbatas. \\
\hline Tingkat Kontestasi & \\
& - Berjalan tidaknya proses seleksi; \\
& - Berjalan tidaknya mekanisme voting; \\
& - Money politics. \\
\hline
\end{tabular}

\section{LANDASAN TEORI}

\subsection{Partai Politik}

Mengenai apa yang dimaksud dengan istilah political party (partai politik), banyak sarjana-sarjana ilmu politik yang berpendapat dengan pengertian yang berbedabeda, akan tetapi perbedaan-perbedaan tersebut tidak terlalu signifikan. Adanya perbedaan dari pengertian mengenai istilah partai politik tersebut disebabkan oleh adanya perbedaan sudut pandang atau approach dari masing-masing sarjana terhadap partai politik tersebut.

Dari beberapa pengertian dari partai politik, maka dapat ditarik empat pokok utama, yaitu:

- Ada beberapa perangkat yang melekat pada partai politik yang merupakan sekumpulan orang yang terorganisasi.

- Partai politik memiliki tujuan untuk memperoleh dan mempertahankan kekuasaan.

- Untuk merealisasikan tujuannya ini, partai politik berusaha memperoleh dukungan yang seluas-luasnya dari masyarakat melalui pemilihan umum.

- Partai politik memiliki prinsip-prinsip yang disetujui bersama antar anggota partai politik tersebut. ${ }^{11}$

\footnotetext{
${ }^{11}$ M. Soebiantoro et al., Pengantar Ilmu Politik, (Universitas Jenderal Soedirman, Purwokerto, 2000), hlm. 86
} 
Jadi inti dari partai politik adalah bahwa partai politik merupakan wahana atau sarana bagi sekelompok orang untuk meraih tujuan tertentu, termasuk dalam hal ini partai politik adalah wadah bagi seseorang untuk menjadi kandidat kepala daerah.

Terkait dengan penelitian mengenai mekanisme rekruitmen calon bupati pada Pemilihan Umum Kepala Daerah secara Langsung tahun 2015, dengan para kandidat yang bersaing membawa nama partai politik. Maka dari itu peneliti mengambil satu dari beberapa fungsi partai politik, yakni fungsi rekruitmen politik sebagai salah satu acuan dalam penelitian.

\subsection{Pemilihan Umum}

Menurut Ramlan Surbakti ${ }^{12}$, tujuan dari pemilihan umum ada tiga, yaitu:

- Pemilihan umum sebagai mekanisme untuk menyeleksi para pemimpin pemerintah dan alternatif kebijakan umum, atau mekanisme penyeleksian dan pendelegasian atau penyerahan kedaulatan kepada orang atau partai yang dipercaya.

- Pemilihan umum sebagai mekanisme memindahkan konflik kepentingan dari masyarakat kepada badan perwakilan rakyat melalui wakil rakyat yang terpilih, atau melalui partai-partai yang memenangkan kursi sehingga integrasi masyarakat tetap terjamin.

- Pemilihan umum merupakan sarana memobilisasikan dan menggalang dukungan rakyat terhadap negara dan pemerintahan dengan jalan ikut serta dalam proses politik.

Pembukaan peluang bagi politisi di luar parlemen yang ada untuk berkompetisi dalam arena terbatas, bukan hanya lewat partai politik lokal, melainkan juga melalui pemilihan umum lokal. Pemilihan umum lokal menjadi satu jalan keluar bagi luasnya wilayah Indonesia, serta terbatasnya kemampuan infrastruktur penyelenggaraan dan pengawasan pemilihan umum. Pemilihan umum lokal

\footnotetext{
12 Bambang Kuncoro, Konstelasi Politik Menjelang Pemilihan Umum 2004, dalam Swara Politika Jurnal Politik dan Pembangunan, Vol. 3, No. 2 (Oktober, 2003), hlm. 3
} 
menjadi sarana pencegahan ketertutupan politik oleh para pelakunya, terutama yang berkaitan dengan partai politik di tingkat nasional. Pemilihan umum lokal juga menjadikan sarana pemandirian penyelenggaraan dan pengawasan politik lokal, mengisi local contents, dan pembenahan aspek-aspek lainnya dalam wilayah politik lokal.

\subsection{Rekruitmen Politik}

Menurut Eugene McKenna, rekruitmen merupakan proses penarikan sekelompok kandidat untuk mengisi posisi yang lowong. ${ }^{13}$ Rekruitmen dapat dilakukan karena adanya kepentingan politik di balik itu. Rekruitmen yang dilakukan untuk kepentingan politik misalnya untuk mengisi lembaga-lembaga negara yang bersifat politik. ${ }^{14}$

Perlu dibedakan antara Classified Positions dan Exempt Positions dalam konsep rekruitmen. Classified positions biasanya diisi melalui birokrasi atau sistem pelayanan sipil. Jadi, rekruitmen jenis ini merupakan pemilihan berdasarkan karier atau pengalaman kerja, sedangkan Exempt Positions berada di luar mekanisme birokrasi atau pelayanan sipil, dan yang pasti ada pertimbangan politik dari pemilihan melalui tipe ini. ${ }^{15}$

Di dalam sistem politik, terdapat prosedur-prosedur untuk melaksanakan rekruitmen atau penyeleksian. Walaupun prosedur-prosedur yang dilaksanakan oleh tiap-tiap sistem politik berbeda-beda satu dengan lainnya, namun terdapat satu kecenderungan bahwa individu-individu berbakat yang dicalonkan untuk menduduki jabatan politik maupun pemerintahan mempunyai latar belakang yang hampir sama, yaitu bahwa mereka berasal dari kelas menengah atau kelas atas, dan kalaupun mereka berasal dari kelas bawah tetapi mereka merupakan orang-orang yang telah memperoleh pendidikan yang memadai. ${ }^{16}$

\footnotetext{
${ }^{13}$ Ambar Teguh Sulistyani, Memahami Good Governance: Dalam Perspektif Sumber Daya Manusia, (Gava Media, Yogyakarta, 2004), hlm. 134

${ }^{14}$ Ibid., hlm. 147

${ }^{15}$ Ibid., hlm. 148

${ }^{16}$ Mochtar Mas'oed dan Colin Mac Andrew, Perbandingan Sistem Politik, (Gadjah Mada Press, Yogyakarta, 1997), hlm. 47
} 
Mengenai perihal cara pelaksanaan rekruitmen politik, pada umumnya dikenal ada dua cara perekruitan, yaitu yang dilakukan secara terbuka dan yang secara tertutup. ${ }^{17}$ Adapun yang dimaksud dengan rekruitmen politik terbuka adalah bahwa rekruitmen terbuka bagi seluruh warga negara. Seluruh warga negara tanpa kecuali mempunyai kesempatan yang sama untuk direkruit apabila yang bersangkutan telah memenuhi syarat-syarat yang telah ditentukan. Yang dimaksud dengan rekruitmen politik tertutup adalah bahwa individu-individu tertentu saja yang dapat direkruit untuk kemudian menduduki jabatan politik maupun pemerintahan. Dalam pola rekruitmen ini kesempatan tidak dibuka bagi seluruh warga negara, namun hanya dilakukan terhadap individu-individu tertentu saja. ${ }^{18}$

\subsection{Pemilihan Kepala Daerah secara Langsung}

Sesungguhnya bukan hanya kepala daerah saja yang dapat dipilih secara langsung. Evans ${ }^{19}$ berpendapat bahwa di tingkat lokal, termasuk bagian eksekutif dan legislatif, yang paling maksimal dapat dipilih oleh rakyat adalah:

- Eksekutif: Gubernur, Bupati, Walikota, Camat, Kepala Desa atau Lurah, Ketua Rukun Warga, dan Ketua Rukun Tetangga.

- Legislatif: DPRD Provinsi, DPRD Kabupaten/Kota, Badan Perwakilan Kecamatan, Badan Perwakilan Desa, Dewan Kelurahan, Badan Perwakilan RW, dan Badan Perwakilan RT.

Ada beberapa hal yang perlu diperhatikan dalam proses Pemilian Kepala Daerah secara Langsung, yaitu:

- Proses Pemilihan Kepala Daerah secara Langsung melibatkan peran aktor di luar pemerintah;

- Dalam rangka proses Pemilihan Kepala Daerah secara Langsung, warga masyarakat dapat menyalurkan aspirasi calon pada organisasi nonpemerintah, partai politik, pers, stakeholders dan lain-lain;

- Calon dapat berasal dari partai politik, organisasi nonpolitik, atau individual (independen);

- Pemerintah pusat, pemerintah daerah, dan DPRD berperan sebagai fasilitator;

\footnotetext{
${ }^{17}$ Haryanto, Sistem Politik Suatu Pengantar, (Liberty, Yogyakarta, 1984), hIm. 47

${ }_{18} \mathrm{Ibid}$., hlm. 48

${ }^{19}$ Analisis CSIS, Politik Lokal Pasca Amandemen Konstitusi: Mencari Peluang Perubahan, (CSIS, Tahun XXXII, No. 1, Jakarta, 2003), hIm. 119
} 
- Preferensi masyarakat tecermin dalam tahap-tahap pelaksanaan Pemilihan Kepala Daerah secara Langsung, baik pada saat prapemilihan, pemilihan, dan pasca pemilihan.

Dari proposisi-proposisi di atas, dapat dihasilkan proposisi dasar, yaitu pemilihan kepala daerah secara langsung yang demokratis adalah proses rekruitmen yang dapat menghasilkan kepala daerah dan wakil kepala daerah yang sesuai dengan preferensi masyarakat dan mekanismenya mencerminkan partisipasi masyarakat secara aktif, maksimal dan transparan serta menjamin kontestasi calon. ${ }^{20}$

\subsection{Demokrasi di Tingkat Lokal}

Paradigma yang sesuai dengan penyelenggaraan pemerintahan daerah adalah "demokratisasi", karena pemerintahan harus berjalan secara transparan, penuh keterbukaan, dan semakin menumbuhkan peran dan kemampuan masyarakat untuk melibatkan diri dalam proses pengambilan keputusan penyelenggaraan pemerintahan dan pembangunan. ${ }^{21}$

Asep Nurjaman dalam Andi Mallarangeng ${ }^{22}$ menyatakan bahwa pada umumnya perspektif teori liberal tentang negara berpendapat bahwa demokrasi lokal memberi kontribusi yang positif terhadap kesehatan demokrasi nasional. Hal ini dikarenakan banyaknya kesempatan bagi berkembangnya partisipasi dalam menentukan kebijakan pemerintahan, karena adanya iklim demokrasi yang menghargai pendapat dan kebebasan berbicara. Dengan demikian, demokrasi lokal menjadi sangat besar perannya dalam mendukung demokrasi nasional. Secara nyata dampaknya menjadi jelas, bahwa pemberian otonomi yang seluas-luasnya pada daerah justru akan sangat berpengaruh pada kehidupan demokrasi negara secara keseluruhan.

Berbagai pandangan yang menyebutkan bahwa pemerintahan daerah merupakan cara yang terbaik dalam memberi pelayanan terhadap masyarakat, pada dasarnya berdasar pada dua asumsi. Pertama, kehidupan demokrasi di tingkat pemerintahan

\footnotetext{
${ }^{20}$ Solahudin Kusumanegara, Perspektif Teoritik Pilkada Langsung, dalam Swara Politika Jurnal Politik dan Pembangunan, Vol. 6, No. 1, (2005), hlm. 18-22

${ }^{21}$ Andi Alfian Mallarangeng, Otonomi Daerah Perspektif Teoritis dan Praktis, (BIOGRAF Publishing, Yogyakarta, 2001), hlm. 116

22 Ibid., hlm. 129
} 
daerah akan berimbas pada baiknya kehidupan demokrasi di tingkat nasional. Pada tingkat nasional ini terkait dengan pendidikan politik, training dalam kepemimpinan politik. Kedua, mengembangkan kehidupan demokrasi di tingkat daerah mempunyai manfaat yang sangat besar, seperti berkembangnya kesamaan (equality), kebebasan (liberty), dan bersikap tanggap (responsiveness). ${ }^{23}$

\section{PEMBAHASAN}

\subsection{Lokasi Penelitian}

Penelitian ini dilaksanakan di Kantor DPD Partai Amanat Nasional Kabupaten Lampung Selatan yang terletak sekitar $1,41 \mathrm{~km}$ ke arah barat laut dari Kota Kalianda. Penentuan lokus penelitian didasari oleh beberapa alasan, antara lain, DPD Partai Amanat Nasional berhasil memenangkan calon yang diusung untuk mengalahkan calon petahana, yang memiliki basis dukungan yang kuat di wilayah Lampung Selatan. Sudah tentu, tidak semua pengurus partai dijadikan informan karena penelitian ini bersifat kualitatif. Penelitian ini tidak bermaksud untuk generalisasi tapi hanya ingin mengetahui seperti apa proses rekruitmen calon bupati yang dilakukan oleh partai. Hanya 6 orang dari mereka untuk dijadikan informan, yang semuanya laki-laki.

\subsection{Sekilas Tentang DPD Partai Amanat Nasional Lampung Selatan}

Partai Amanat Nasional (PAN) di Lampung Selatan terdiri dari 17 (tujuh belas) DPC (Dewan Pimpinan Cabang), DPC ini merupakan kesatuan organisasi dan kepemimpinan yang berada di tingkat kecamatan, jadi di 17 kecamatan di Kabupaten Lampung Selatan telah ada kepengurusan PAN.

Mengenai struktur organisasi DPD PAN Kabupaten Lampung Selatan terdiri dari Ketua, Sekretaris, dan Bendahara. Ketua disini membawahi 10 (sepuluh) bidang kepengurusan. Kesepuluh bidang kepengurusan ini yaitu yang pertama adalah bagian Koordinasi Organisasi Otonom dan Kerjasama Antar Lembaga; kedua, bagian Advokasi, Hukum dan Hak Asasi Manusia; ketiga, bagian Ekonomi, Koperasi, Jaringan Usaha dan Wirausaha; keempat; bagian Perkaderan; kelima,

${ }^{23}$ Ibid., hlm 129 
bagian Pengembangan Organisasi dan Keanggotaan (POK); keenam, bagian Sistem Informasi dan Komunikasi Politik; ketujuh, bagian Pemberdayaan Perempuan; kedelapan, bagian Penelitian dan Pengembangan; kesembilan, bagian Kebijakan Publik; kesepuluh, bagian Kesehatan, Pendidikan dan Kebudayaan; kesebelas, bagian Pembinaan dan Pemenangan Pemilu Daerah.

Menurut pemaparan pengurus, menjelang Pemilihan Kepala Daerah secara Langsung tahun 2015 di Kabupaten Lampung Selatan, semua unsur-unsur yang terlibat dalam struktur organisasi ini saling bekerjasama secara maksimal, dan hasilnya adalah kesuksesan dalam proses rekruitmen calon bupati hingga keberhasilan dalam peningkatan perolehan suara. Optimalisasi pemberdayaan seluruh sumber daya manusia yang dilakukan oleh partai, baik untuk sumber daya manusia yang terlibat secara langsung dalam struktur organisasi maupun yang tidak terlibat secara langsung terbukti memberikan hasil yang optimal pula.

Menurut Ketua DPD PAN Lampung Selatan, untuk masuk menjadi anggota ataupun pengurus partai dilakukan dengan cara-cara yang demokratis, PAN sebagai partai yang terbuka menerima kalangan manapun sebagai pengurus ataupun sebagai anggota asalkan pribadi tersebut memiliki kemampuan dan kepribadian baik maka partai siap menerima sebagai kader. PAN dengan kelengkapan organisasinya dapat lebih mampu meraih dan melaksanakan program kerjanya dengan maksimal.

\subsection{Riwayat Informan}

Subjek pada penelitian ini adalah:

1. Azmi Aziz

Ketua DPD PAN Lampung Selatan periode 2010-2015

2. Ahmad Arifin

Anggota DPRD II Lampung Selatan periode 2009-2014

3. Ahmad Salasi

Kader Muda PAN Lampung Selatan 


\section{Ahmat Fitoni}

Sekretaris DPD PAN Lampung Selatan periode 2010-2015

\section{Sugianto}

Bendahara DPD PAN Kabupaten Lampung Selatan periode 2010-2015

Subjek penelitian merupakan pihak-pihak yang terlibat langsung dalam proses rekruitmen bakal calon, calon, hingga penetapan calon sebagai pemimpin yang terpilih. Peneliti menentukan subjek penelitian tersebut dengan pertimbangan mereka dirasa mampu memberikan data dan informasi mengenai proses rekruitmen calon bupati oleh PAN di Kabupaten Lampung Selatan.

\subsection{Proses Rekruitmen Calon Bupati oleh Partai Amanat Nasional}

Untuk mensukseskan pelaksanaan Pemilihan Kepala daerah secara Langsung di Lampung Selatan pada tahun 2015, PAN mengadakan rekruitmen untuk memilih calon atau kandidat kepala daerah yang akan dipilih langsung oleh masyarakat.

Adapun dasar pertimbangan dari partai untuk mengadakan rekruitmen adalah UU No. 32/2004 tentang Pemerintahan Daerah pasal 56 ayat 1, yang mengisyaratkan bahwa Bupati dan Wakil Bupati dipilih dalam satu pasangan calon yang dilaksanakan secara demokratis, dan pasal 59 ayat 3 yang intinya menyebutkan bahwa partai politik atau gabungan partai politik wajib membuka kesempatan yang seluas-luasnya bagi bakal calon perseorangan yang memenuhi syarat dan selanjutnya memproses bakal calon dimaksud melalui mekanisme yang demokratis dan transparan.

Hal ini sejalan dengan salah satu fungsi penting partai politik, yaitu fungsi sebagai sarana rekruitmen politik, dalam hal ini adalah fungsi partai dalam merekruit bakal calon Bupati/Walikota untuk dapat berpartisipasi dalam Pemilihan Kepala Daerah secara langsung yang dilaksanakan di Indonesia.

Langkah pertama sebelum proses rekruitmen dijalankan adalah membentuk suatu tim yang dinamakan Tim Penjaringan dan Penyaringan bakal calon Bupati dan Wakil Bupati Kabupaten Lampung Selatan. Ketua tim penjaringan dan 
penyaringan calon bupati dan wakil bupati mempunyai tugas selain sebagai penanggung jawab jalannya proses rekruitmen, juga harus dapat mengatur anggotanya untuk bekerja secara profesional agar proses rekruitmen dapat berjalan dengan baik. Selain itu juga keberhasilan jalannya proses rekruitmen sangat dipengaruhi oleh kerjasama yang baik di antara Tim Penjaringan dan Penyaringan calon bupati dan wakil bupati.

Wakil Ketua Tim Penjaringan dan Penyaringan bertugas membantu ketua dalam menyelesaikan tugas-tugasnya dan mewakili ketua jika berhalangan hadir, sehingga tugas-tugas ketua dapat terselesaikan dengan baik meskipun ketua tidak ada. Adapun tugas dari tim tersebut di atas adalah diantaranya melaksanakan administrasi yang berkaitan dengan kegiatan penjaringan dan penyaringan, penetapan pasangan bakal calon; penetapan pasangan calon, dan yang berkaitan dengan kelengkapan berkas pencalonan ke KPUD; mengadakan rapat tim, rapat pengurus harian dan pengurus pleno; melakukan koordinasi dan konsultasi dengan berbagai pihak; melakukan seleksi bagi bakal calon terpilih; dan melaksanakan kegiatan uji publik apabila terdapat pengaduan.

Proses penjaringan dan penyaringan ini mengacu pada tiga aspek, diantaranya dilakukan secara demokratis berdasarkan asas langsung, umum, bebas, rahasia, jujur, dan adil; berasaskan musyawarah untuk mufakat, kebersamaan dan kekeluargaan; dan mengutamakan asas kualitas untuk kepentingan umum. Adapun tahap kegiatan yang dilakukan oleh Tim Penjaringan dan Penyaringan ini meliputi empat tahap, yakni Penjaringan tahap I dan II, kemudian Penyaringan Tahap I dan II.

\subsubsection{Penjaringan Tahap I}

Dalam penjaringan tahap I, Tim Penjaringan dan Penyaringan mengadakan pengumuman mengenai pendaftaran bagi siapa saja yang berminat untuk menjadi bakal calon bupati/wakil bupati yang diumumkan melalui media massa, termasuk di dalamnya membuka pendaftaran yang dilakukan melalui pengambilan biodata bagi siapa saja yang mendaftar menjadi bakal calon bupati/wakil bupati, yang mana hal ini merupakan respon partai untuk menyerap aspirasi masyarakat termasuk menjawab tantangan demokrasi langsung di tingkat lokal. 
Terkait dengan persyaratan untuk bisa mendaftar sebagai bakal calon, selain ada persyaratan yang sifatnya umum, ada juga persyaratan yang bersifat khusus, berdasarkan hasil wawancara para bakal calon selain memenuhi persyaratan secara perundang-undangan, harus memenuhi syarat secara internal partai yang mencalonkan, seperti berkomitmen dengan partai, tidak ada komplain dari masyarakat, figur publik, juga dikenal dan mengenal masyarakat dan daerah.

Pasca disebarkannya pengumuman perihal rekruitmen bakal calon termasuk membuka pendaftaran, tahapan selanjutnya adalah pelaksanaan verifikasi dan pencatatan bakal calon yang mengambil formulir pendaftaran. Akhirnya terkumpullah sebanyak 5 pendaftar yang diantaranya 2 orang mendaftarkan diri menjadi bakal calon (balon) bupati dan sisanya balon wakil bupati.

Kemudian setelah dikembalikannya formulir pendaftaran para bakal calon, maka penjaringan tahap I telah selesai, selanjutnya Tim Penjaringan dan Penyaringan mengadakan penelitian daftar riwayat hidup para bakal calon pada yang hasilnya kemudian dibawa ke rapat pleno partai.

\subsubsection{Penjaringan Tahap II}

Setelah selesai penjaringan tahap I, maka tahapan selanjutnya memasuki penjaringan tahap II. Panjaringan tahap II ini merupakan suatu rangkaian tak terpisahkan dari penjaringan tahap I karena dalam penjaringan tahap II adalah tahapan mensosialisasikan para bakal calon yang telah mendaftar. Hal ini dilakukan untuk memberikan kesempatan bagi masyarakat untuk melakukan koreksi ataupun pengaduan terhadap bakal calon yang ada.

Untuk menghindari kesan tertutup dalam proses rekruitmen, maka para bakal calon disosialisasikan sehingga masyarakat secara langsung mengenal dan tahu siapa saja bakal calon yang telah melewati Penjaringan Tahap I. Hal ini untuk memberikan kesempatan kepada masyarakat untuk melakukan koreksi ataupun pengaduan terhadap bakal calon yang ada. Adapun sosialisasi dilakukan melalui media massa, termasuk lewat surat dari masing-masing partai. 
Setelah sosialisasi selesai, selanjutnya partai mengadakan rapat pleno yang membahas laporan tim mengenai para bakal calon yang telah mengajukan pendaftaran yang berjumlah 5 pendaftar. Kemudian dengan berbagai pertimbangan teknis dan hasil dari rapat Tim Penjaringan dan Penyaringan, diputuskan bahwa kesemua bakal calon tetap lolos untuk mengikuti tahapan selanjutnya yaitu fit and proper test.

\subsubsection{Penyaringan Tahap I}

Setelah tahap penjaringan selesai, maka kegiatan tim dilanjutkan ke tahapan berikutnya yaitu Penyaringan Tahap I. Disini sebanyak 5 bakal calon menjalani fit and proper test yang dilakukan oleh Tim Penjaringan dan Penyaringan, dimana sebelum itu para bakal calon diundang untuk menerima penjelasan-penjelasan kegiatan penyaringan bakal calon menjadi calon yang akan dilakukan melalui penetapan dalam Musyawarah Daerah.

Adapun 5 bakal calon yang mengikuti fit and proper test adalah: Zainudin Hasan (Bupati); Sholeh Bajuri (Bupati); Eki Setyanto (Wakil Bupati); Nanang Ermanto (Wakil Bupati); Antoni Imam (Wakil Bupati). Proses berikutnya adalah pemberitahuan hasil fit and proper test kepada para bakal calon yang hasilnya adalah semua bakal calon tetap maju untuk mengikuti proses dan tahapan berikutnya.

\subsubsection{Penyaringan Tahap II}

Setelah berbagai proses dan tahapan di atas dilaksanakan, tahapan selanjutnya adalah Penyaringan Tahap II. Sesuai dengan mekanisme partai, bahwa proses penjaringan dan penyaringan bakal calon sudah sampai pada tahap penetapan pasangan calon, yang dilakukan melalui sebuah rapat bernama Musyawarah Daerah.

Musyawarah Daerah adalah sebuah forum yang berwenang untuk membahas halhal yang strategis dalam penyaluran aspirasi dan akomodasi kepentingan partai. Adapun Musyawarah Daerah (Musda) kali ini membahas tentang pasangan calon Bupati/Wakil Bupati dari PAN yang merupakan kelanjutan dari tahap-tahap penjaringan dan penyaringan bakal calon. 
Musyawarah Daerah Partai Amanat Nasional Kabupaten Lampung Selatan ini dihadiri oleh peserta yang terdiri dari utusan DPW Provinsi Lampung, unsur Koordinator Wilayah DPW, utusan DPD, utusan DPC, utusan organisasi sayap (BM PAN, Pandu Indonesia, PUAN, PARRA Indonesia, dan GMN).

Setelah sesi demi sesi rapat berjalan, akhirnya dengan berbagai pertimbangan dan kajian strategis, maka diputuskanlah untuk menetapkan Zainudin Hasan sebagai kader partai dan Nanang Ermanto dari PDIP sebagai calon bupati/wakil bupati terpilih yang akhirnya secara aklamasi diterima semua pihak. Adapun pihak yang tidak terpilih seperti Sholeh Bajuri, akhirnya mencalonkan diri melalui PKB dan Gerindra, dan Eki Setyanto yang merupakan kader Partai Demokrat, yang sedari awal digadang-gadang sebagai calon kuat pendamping Zainudin, memilih tetap mendampingi Rycko Menoza, petahana yang didukung Golkar, Demokrat, Hanura dan PBB. Kemudian Antoni Imam selaku kader PKS, memutuskan untuk menjadi tim sukses bagi pasangan Zainudin - Nanang.

Adapun dengan dipilihnya Nanang Ermanto dari PDIP sebagai pendamping Zainudin Hasan juga memiliki tujuan politis, mengingat suara PDIP di Lampung Selatan pada pemilu legislatif 2014 cukup besar dimana PDIP memenangkan pemilu legislatif dan meraih $17 \mathrm{kursi}$, maka diharapkan pasangan ini dapat mendulang suara yang cukup besar dari simpatisan PDIP di wilayah Lampung Selatan.

Selanjutnya pasangan calon tersebut diajukan ke DPW Provinsi Lampung untuk menjalani tahap selanjutnya. Ketentuan tersebut berdasarkan rekomendasi dari Musyawarah Daerah mengenai pasangan calon seperti tersebut untuk diproses lebih lanjut oleh DPW PAN Provinsi Lampung. Dari DPW disahkan lagi dalam Rapat Pleno dan selanjutnya dilaporkan ke dewan penasehat dan DPW untuk mendapatkan persetujuan. Dan pasca rapat DPW PAN, maka diputuskanlah Penetapan Calon Bupati dan Wakil Bupati Kabupaten Lampung Selatan Periode 2016-2021 dari Partai Amanat Nasional yang memutuskan pasangan Dr. H. Zainudin Hasan, M.Hum. - Nanang Ermanto sebagai calon bupati dan wakil bupati dari PAN Kabupaten Lampung Selatan yang juga didukung PKS, PDIP, dan Partai Nasdem. Dengan demikian berakhirlah tahap demi tahap dari proses rekruitmen calon Bupati Lampung Selatan dari DPD PAN. 


\subsection{Pola Rekruitmen Calon Bupati oleh Partai Amanat Nasional}

Dari hasil penelitian, proses rekruitmen calon bupati yang dilakukan oleh partai berjalan demokratis, hal ini dapat dijelaskan sebagai berikut: pertama, partai memberi kesempatan yang luas kepada siapa saja baik anggota partai maupun golongan independen untuk mencalonkan diri menjadi calon bupati/wakil bupati, semua mendapat kesempatan dan perlakuan yang sama. Kedua, dalam penjaringan tahap II, para bakal calon yang sudah diterima disosialisasikan kepada khalayak melalui pengumuman-pengumuman dengan tujuan memperoleh berbagai respon. Jadi, partai tetap mendengarkan berbagai masukan dari masyarakat dalam meloloskan bakal calon ke tahap berikutnya. Ketiga, setiap kegiatan rapat yang diadakan bersifat terbuka, para wartawan dipersilakan untuk meliput dan mengambil risalah rapat termasuk dalam Musyawarah Daerah yang merupakan tahap akhir proses rekruitmen. Keempat, tidak adanya dominasi ketua dalam rapat menunjukkan bahwa ketua dapat mengambil peran untuk tidak berlaku otoriter yang memungkinkannya bertindak secara sepihak. Kelima, tidak terjadi hal-hal yang mengganggu jalannya rapat termasuk penetapan calon bupati terpilih yang berlangsung secara sportif dan dapat diterima semua pihak.

Terkait dengan terpilihnya kader partai dalam tahap akhir proses rekruitmen, maka berdasarkan hasil wawancara, dapat dianalisis bahwa DPD Partai Amanat Nasional Kabupaten Lampung Selatan dalam mekanisme rekruitmen calon bupatinya tidak lepas dari kepentingan dan pertimbangan tertentu dari berbagai pihak termasuk komitmen politik dengan partai yang kemudian mempengaruhi hasil akhir dari proses rekruitmen yang telah berlangsung, yakni partai lebih memprioritaskan kader partai agar ada jaminan bahwa kepentingan-kepentingan dari berbagai pihak melalui partai termasuk dari partai sendiri dapat lebih terartikulasi apabila yang memegang kendali pemerintahan adalah kader partai, sehingga partai dapat berperan lebih dalam pemerintahan melalui kepanjangan tangannya yang ditetapkan menjadi Kepala Daerah. Maka dari itu konsep rekruitmen oleh partai lebih cenderung kepada Exempt Positions atau rekruitmen yang didasarkan pada pertimbangan politik tertentu.

Mengenai karakteristik dari orang-orang yang dipilih secara politik bila dikaitkan dengan terpilihnya kader partai menjadi calon terpilih dari PAN dapat diindikasikan sebagai berikut: 
Pertama, penetapan kader partai menjadi calon bupati yang dipilih oleh PAN tentu memiliki alasan yang bersifat politis. Secara logika politik, kader partai yang menduduki suatu jabatan politik tentunya mempunyai suatu keterikatan dengan partainya baik secara politik maupun secara ideologi sehingga komitmen politik dapat lebih terjaga dan kepentingan politik dapat lebih terprioritaskan dibandingkan dengan non kader. Maka dari itu sangatlah wajar apabila partai lebih mendahulukan kader daripada non kader dalam panggung politik walaupun secara aturan main non kader juga berhak dipilih oleh partai. Penetapan Zainudin hasan menjadi calon bupati dari PAN tentunya juga tak lepas dari loyalitas serta pengabdian beliau kepada partai sehingga turut membesarkan partai.

Kedua, dalam hal proses rekruitmen di tubuh partai, disini partai lebih memilih calon yang berpengalaman dalam pertarungan Pemilukada. Adapun Zainudin Hasan memiliki pengalaman mencalonkan diri pada Pemilukada Lampung Selatan 2010 berpasangan dengan Ikang Fawzi. Jadi berbekal pengalaman inilah Zainudin Hasan dianggap sudah dikenal oleh masyarakat, serta belajar dari kekalahan sehingga memahami seluk-beluk dan strategi pemenangan untuk bertarung di Pemilukada Lampung Selatan 2015. Jadi dapat dilihat disini bahwa partai lebih berorientasi pada pengalaman dan public figure, yang artinya partai tidak mau mengambil resiko dengan menetapkan calon yang sama sekali belum berpengalaman walaupun mungkin memiliki kapasitas intelektual yang lebih baik.

Ketiga, calon terpilih dari PAN yaitu Zainudin Hasan, merupakan kader partai sekaligus mempunyai latar belakang sebagai seorang pengusaha sukses. Dalam beberapa kasus, jabatan-jabatan politik strategis biasanya diisi oleh kalangan elit ekonomi, hal ini dikarenakan mereka mempunyai modal yang kuat sehingga mampu berperan lebih dan dominan serta berpengaruh besar dalam suatu sistem politik sehingga mereka dapat lebih mudah meraih apa yang diinginkan termasuk menguasai sistem politik melalui kekuatan finansial mereka.

\subsection{Tingkat Kontestasi}

Dengan adanya tingkat kontestasi, setidaknya dapat menjadi langkah awal yang baik dalam proses menuju pemerintahan daerah yang demokratis, maka dari itu 
untuk mengetahui seberapa kuat tingkat kontestasi berpengaruh dalam proses rekruitmen yang telah dilangsungkan, dapat dilihat dari tahap akhir proses rekruitmen yaitu penyaringan yang terdiri dari dua tahap yaitu penyaringan tahap I atau tahap fit and proper test dan penyaringan tahap II atau penetapan calon.

Dari hasil penelitian, tingkat kontestasi antar bakal calon bupati/wakil bupati yang berlangsung dalam partai cenderung rendah. Ada dua faktor pendukung, pertama, tidak berjalannya proses seleksi bakal calon setelah melewati tahapan fit and proper test dalam tahap penyaringan, hal ini dapat dilihat dari tetap lolosnya kesemua bakal calon setelah melewati tahapan fit and proper test tanpa adanya pengurangan untuk mengikuti tahap akhir dalam proses rekruitmen yang diadakan melalui Musyawarah Daerah.

Seharusnya dalam tahap fit and proper test, Tim Penjaringan dan Penyaringan benar-benar menyeleksi secara ketat para bakal calon yang cakap dan berprestasi yang otomatis akan ada bakal calon yang tersisih sehingga prinsip kontestasi akan lebih terlihat. Selanjutnya mengenai kurangnya tingkat kontestasi, penulis melihat dalam tahap penetapan calon, yang tidak menjalankan mekanisme voting (pemungutan suara) dalam menetapkan pasangan calon. Namun, terpilihnya calon bupati melalui musyawarah para peserta Musda secara demokratis dan dapat diterima semua pihak sedikit mewarnai kontestasi antar bakal calon.

Faktor selanjutnya untuk menganalisis proses rekruitmen calon Bupati Lampung Selatan dalam Partai Amanat Nasional adalah ada tidaknya money politics dalam proses rekruitmen tersebut. Money politics adalah menggunakan uang untuk memenangkan persaingan dalam memperebutkan jabatan politik yang dalam hal ini adalah memperebutkan posisi sebagai calon bupati dengan peluang terpilih menjadi lebih besar. Money politics meskipun sebuah fenomena yang memang benar-benar terjadi namun sangat sulit sekali dibuktikan, hal ini disebabkan karena money politics dilakukan secara sembunyi-sembunyi dan tertutup dengan rapi serta hanya diketahui oleh orang-orang yang berkepentingan saja.

Berdasarkan hasil wawancara terhadap para informan yang cenderung menampik adanya kemungkinan praktek money politics dalam proses rekruitmen calon bupati oleh partai, sulit bagi penulis untuk membuktikan ada tidaknya money politics dalam proses rekruitmen yang telah berlangsung. Namun dalam setiap sistem politik, terlepas dari hal itu merupakan money politics atau bukan, sudah 
merupakan hukum alam bahwa uang dan politik tidak dapat dipisahkan, karenanya, merupakan hal yang manusiawi bila setiap institusi politik khususnya partai politik membutuhkan dana bagi operasional partai demi kelangsungan hidup partai yang bersangkutan.

Jadi keberadaan uang dalam setiap proses politik merupakan hal yang niscaya, yang sampai kapan pun tidak akan pernah dapat dihilangkan. Maka itu, sangatlah naif apabila ada apabila ada pandangan bahwa seseorang dapat meraih kekuasaan tanpa dukungan modal, hal ini tidaklah mungkin dan tidak akan pernah terjadi mengingat uang adalah sarana untuk meraih kekuasaan termasuk dalam hal ini adalah untuk menduduki jabatan sebagai Kepala Daerah.

Maka dari itu penulis beranggapan bahwa money politics dalam proses rekruitmen calon bupati yang dilakukan oleh partai memang ada dengan persentase yang kecil mengingat sebagian besar informan menampik terjadinya praktek money politics dalam prosesnya.

\section{KESIMPULAN DAN SARAN}

Rekruitmen calon bupati/wakil bupati di tubuh Partai Amanat Nasional Lampung Selatan ini dari awal sampai dengan akhir prosesnya bersifat terbuka dan demokratis. Indikatornya adalah pertama, pendaftaran terbuka untuk umum, yang artinya tidak ada monopoli kader partai dalam hal pencalonan. Kedua, proses penetapan calon dalam tahap akhir bersifat terbuka dan berjalan secara demokratis melalui musyawarah serta dapat diterima semua pihak, namun ada beberapa catatan, yakni kurangnya kontestasi antar bakal calon yang dilihat melalui tidak adanya seleksi dalam tahap penyaringan termasuk tidak dijalankannya mekanisme voting.

Terkait dengan saran, maka berkaitan dengan pelaksanaan Pemilihan Umum Kepala Daerah secara Langsung dan proses rekruitmen calon bupati yang dilakukan oleh partai pada khususnya, ke depan hendaknya mekanisme voting benar-benar dijalankan sebagai salah satu wujud dukungan DPD Partai Amanat Nasional terhadap pendidikan politik masyarakat dan cerminan tingkat kontestasi yang tinggi dari proses politik yang berjalan serta tetap mempertahankan prinsip 
demokrasi yang diwujudkan melalui proses rekruitmen yang terbuka dan dapat diterima semua pihak.[] 


\section{DAFTAR PUSTAKA}

Analisis CSIS, 2003, Politik Lokal Pasca Amandemen Konstitusi: Mencari Peluang Perubahan, CSIS, Tahun XXXII/2003 No 1, Jakarta

Haryanto, 1984, Sistem Politik Suatu Pengantar, Liberty, Yogyakarta

Kaloh, J., 2002, Mencari Bentuk Otonomi Daerah, Penerbit Rineka Cipta, Jakarta

Kuncoro, Bambang, Konstelasi Politik Menjelang Pemilihan Umum 2004, Swara Politika Jurnal Politik dan Pembangunan, Vol 6 No 1, 2005

Kusumanegara, Solahudin, Perspektif Teoritik Pilkada Langsung, Swara Politika Jurnal Politik dan Pembangunan, Vol 6 No 1, 2005

Mallarangeng, Andi Alfian, dkk., 2001, Otonomi Daerah Perspektif Teoritis dan Praktis, BIOGRAF Publishing, Yogyakarta

Mas'oed, Mochtar dan Colin Mac Andrew, 1997, Perbandingan Sistem Politik, Gadjah Mada Press, Yogyakarta

Meyer, Thomas, 2003, Demokrasi Sebuah Pengantar untuk Penerapan, FES Kantor Perwakilan Indonesia, Jakarta

Moleong, Lexy J, 2004. Metode Penelitian Kualitatif, PT Remaja Rosdakarya, Bandung.

Siahaan, Maruarar, 2005, Pemilihan Kepala Daerah dalam Demokrasi Transisional, Mahkamah Konstitusi Republik Indonesia, Jakarta

Soebiantoro, M., dkk., 2000, Pengantar Ilmu Politik, Universitas Jenderal Soedirman, Purwokerto

Soebiantoro, M., Pemilihan Kepala Daerah Langsung dan Dilema Demokratisasi di Tingkat Lokal, Makalah Seminar Nasional, 2005, Jurusan Ilmu Politik, UNSOED, Purwokerto

Sulistyani, Ambar Teguh, 2004, Memahami Good Governance: Dalam Perspektif Sumber Daya Manusia, Gava Media, Yogyakarta

Syafiie, Inu Kencana, dkk., 2002, Sistem Pemerintahan Indonesia, PT Rineka Cipta, Jakarta Syaukani, H.R., dkk., 2004, Otonomi Daerah dalam Negara Kesatuan, Pustaka Pelajar, Yogyakarta

https://pilkada2015.kpu.go.id/lampungselatankab 